\title{
LA VARIANTE EN EL ROMANCERO MANUSCRITO E IMPRESO DEL SIGLO XVI: PAUTAS EN LA CORRECCIÓN DE COPISTAS, IMPRESORES Y AUTORES ${ }^{1}$
}

\author{
A Antonio Carreira, a Ralph DiFranco \\ y a José J. Labrador Herraiz, con gratitud, \\ por las puertas que han abierto \\ para estas páginas
}

\begin{abstract}
Algunos lugares comunes sobre el Romancero DEL SIGLO XVI: ANONIMIA Y TRANSMISIÓN IMPRESA
\end{abstract}

"La perfidia del lugar común", escribía Giuseppe Di Stefano en 1992, "no consiste en que esconde una total falsedad, sino en que contiene una verdad, pero tan abultada e insistida que quien descubre en él alguna fisura tiende por reacción a declararlo falso por entero" ${ }^{\text {. }}$. El tema que avanza el subtítulo sobre la anonimia y consecuente tradicionalidad del Romancero manuscrito e impreso, primer corpus sustantivo de este género literario en llegar hasta nuestro días, contiene una gran verdad, pero con fisuras. Aunque etiquetas como Romancero viejo y nuevo nos ayudan a distinguir entre un Romancero anónimo y otro fuertemente ligado al prestigio de sus autores, escrito mayoritariamente a partir de 1580, en el fondo se trata de

1 Este trabajo se enmarca en el proyecto La variante en la imprenta: hacia un canon de transmisión del cancionero y del romancero medievales, financiado por el Ministerio de Economía y Competitividad (FFI2011-25266) y coordinado por Josep Lluís Martos como investigador principal.

${ }^{2}$ Giuseppe Di Stefano, "El Romance del conde Alarcos en sus ediciones del siglo xvi", en Hispanic Studies in Honor of Samuel G. Armistead, ed. de E. Michael Gerli y Harvey L. Sharrer, Hispanic Seminary of Medieval Studies, Madison, 1992, pp. 111-129. 
una estratagema conceptual que da la espalda a la evidencia: si nos remontamos a los primeros años del Romancero impreso, de inmediato se advierte un panorama heterogéneo; mientras en una fecha cercana a 1547-1548, Martín Nucio declaraba haber recopilado "todos los romances que han venido a mi noticia", atento a fuentes impresas ("los ejemplares de adonde los saqué") y orales ("la memoria de algunos que me los dictaron"; aunque hoy Mario Garvin ha podido demostrar que, en su gran mayoría, se trata de textos copiados de pliegos sueltos anteriores $^{4}$ ); Lorenzo de Sepúlveda escribía de su propia musa y publicaba en Sevilla, antes de 1550, saqueando la información histórica de la crónica de Florián de Ocampo $^{5}$, sus Romances sacados nuevamente de historias antiguas de la crónica de España. Mientras uno recopilaba, el otro escribía, con autoría reconocida, "en metro Castellano y en tono de Romances viejos que es lo que agora se usa" 6 . La historia de ambas empresas vendría a confundirse años después en el cauce de la recepción popular, cuando en sus diferentes ediciones la obra de Sepúlveda se conociera, al rescate de la etiqueta Cancionero de Romances, como Cancionero de Romances sacados de las corónicas antiguas de España con otros hechos por Sepúlveda (Granada, 1563; Francisco del Canto, Medina del Campo, 1570 y 1576; Sebastián Martínez, Alcalá de Henares, 1571; Diego Fernández, Valladolid, 1577; Fernando Díaz, Sevilla, 15847).

La idea de un Romancero compuesto por un autor único cuajó en catorce ediciones entre 1550 y 1584, y derivó en una fórmula exitosa durante el siglo Xvi conocida hoy como el Romancero erudito, de estilo popular, pero hechizo a partir de

3 Cancionero de Romances en que estan recopilados la mayor parte delos romances castellanos que fasta agora sean compuesto, Martín Nucio, Amberes, s.a. [15471548], A [2] r-v; cito por el ejemplar de la Bibliothèque National de France, Arsenal, Reserve 8-BL-16, 099.

4 Scripta manent, hacia una edición crítica del Romancero impreso (siglo XVI), Iberoamericana-Vervuert, Madrid-Frankfurt/M., 2007, pp. 167-218.

${ }^{5}$ Las quatro partes enteras dela Cronica de España que mando componer el Serenissimo rey don Alonso llamado el sabio, donde se contienen los acontescimientos y hazañas mayores y mas señaladas que suçedieron en España desde su primera poblacion hasta casi los tiempos del dicho señor rey, vista y emendada mucha parte de su impresion por el maestro Florian Docampo, Agustin de Paz y Juan Pichardo, Zamora, 1541; Biblioteca Nacional de España, R-24, 890

${ }^{6}$ Lorenzo de Sepúlveda, Cancionero de Romances (Sevilla, 1584), ed., est., bib. e índices de A. Rodríguez-Moñino, Castalia, Madrid, 1967, p. 43.

7 Ibid., pp. 71, 83-85, 95, 106. 
fuentes librescas, con ejemplos de la envergadura del Romancero historiado de Lucas Rodríguez, hacia $1579-1580^{8}$, y otros, menos conocidos pero no menos interesantes, como el Romancero en el cual se contienen algunos sucesos que en la jornada de Flandres los españoles hicieron, con otras historias y poesías diferentes, de Pedro de Padilla, en $1583^{9}$. En el ámbito de los cancioneros manuscritos, en el manuscrito 617 de la Biblioteca Nacional de Madrid, concluido entre 1568 y 1571, se encuentra en los últimos folios del manuscrito (ff. 331r-341v) un romancerillo historiado de Juan Sánchez Burguillos sobre Fernán González y Bernardo del Carpio, con composiciones nuevas, generalmente amplificatorias, inspiradas en romances viejos y eruditos previos ${ }^{10}$. La confusión entre romances anónimos y romances de autor llegará a su punto más álgido en el Romancero e historia del muy valeroso caballero el $\mathrm{Cid}^{11}$, de Juan de Escobar, con una variatio retórica por la que se ponen "en concierto" romances eruditos de Sepúlveda y Lucas Rodríguez, romances "viejos" del Cancionero de romances de Nucio, romances "nuevos" de las compilaciones de Timoneda y Madrigal, algunos de pliegos sueltos, otros tantos del Romancero general de $1604^{12}$. A esta silva romanceril, próspera y confusa, habría que agregar los veinticuatro romances sin fuente previa que pudieron haber sido compuestos por Escobar, como una contribución "erudita" de autor para llenar huecos narrativos entre los romances (ibid., pp. 30-31) con lo que el compilador terminaba también metido a "autor de romances".

El lugar común de la anonimia en el Romancero, pese a la evidencia de varios Romanceros de autoría reconocida, ha venido a condicionar con los años otro lugar común: el de las variantes de poca calidad, producidas durante el proceso de transmisión oral o en los talleres de imprenta donde los textos circularían a merced de impresores, correctores, componedo-

${ }^{8}$ Lucas Rodríguez, Romancero historiado (Alcalá, 1582), ed., est. bib. e índices de A. Rodríguez-Moñino, Castalia, Madrid, 1967.

${ }^{9}$ Hay edición reciente en Pedro de Padilla, Romancero, est. de A. Rey Hazas y M. de la Campa, ed. de J.J. Labrador Herraiz y R.A. DiFranco, Frente de Afirmación Hispanista, México, 2010.

${ }^{10}$ Cancionero de poesías varias, manuscrito no. 617 de la Biblioteca Nacional de Madrid, ed., pról., notas e índices de J.J. Labrador, C. Ángel Zorita y R. DiFranco, El Crotalón, Madrid, 1986, núms. 493-508.

${ }^{11}$ Historia y Romancero del Cid (Lisboa, 1605), ed., est. bib. e índices de A. Rodríguez-Moñino; introd. de A. Lee-Francis Askins, Castalia, Madrid, 1973.

${ }_{12}$ Puede verse, con provecho, el estudio de las fuentes de A. LeE-Francis Askins, en ibid. pp. 25-33. 
res y compiladores; en razón de su escasa valía, a menudo desatendidas por la crítica $^{13}$. La desatención con la que ha sido visto el fenómeno puede deberse en primer lugar a la falta de investigaciones sobre los procesos de variación en la imprenta, pero también a otro tópico académico: la preeminencia de la variante de autor sobre cualquier variante de imprenta (de la que podía ser partícipe el corrector, el componedor, el compilador, el impresor), desde la errata y cualquier otra decisión mecánica hasta el remiendo de versos. Se trata de un lugar común activo que termina por colarse hasta en la tipología más persuasiva, como la que propone Alfonso Rey para manuscritos e impresos de El Buscón:

Conviene iniciar el estudio textual del Buscón estableciendo una clara distinción entre variantes de copista, variantes redaccionales y variantes de autor. Considero variantes de copista los errores introducidos involuntariamente en el proceso de copia y los cambios debidos al malogrado propósito de subsanar un error; entiendo por variantes redaccionales las introducidas deliberadamente para modificar el texto, y por variantes de autor las variantes redaccionales debidas al responsable de la obra ${ }^{14}$.

Las cosas aquí no están tan claras como parece a primera vista: si las variantes de autor son en el fondo variantes redaccionales (como apunta Rey, entiende "por variantes de autor las variantes redaccionales"), el deslinde puede no ser tan efectivo; por otra parte, las variantes redaccionales, "introducidas deliberadamente para modificar el texto", se parecen mucho a ciertas variantes de copista, pues el "malogrado propósito de modificar el texto" también coincide con las variantes "introducidas deliberadamente para modificar el texto", sólo que cuando el lance parece "malogrado" por su calidad se atribuye de forma mecánica al copista. En los tres casos, los rasgos distintivos no son textuales, sino valorativos desde la perspectiva de la calidad estética de la variante: si es un error y deturpa el texto sin intención, se atribuye al copista (como si el copista no fuera capaz de introducir variantes redaccionales de calidad); si sólo lo cambia, sin dañar-

${ }^{13}$ Resulta muy aleccionador leer, al respecto, G. Di Stefano, art. cit., p. 111.

14 Alfonso Rey, "El problema textual del Buscón", en Francisco de Quevedo, El Buscón, edición crítica de las cuatro versiones, ed. de A. Rey, CSIC, Madrid, 2007, p. xvi. 
lo en exceso, es una variante redaccional (como si el autor no introdujera variantes de poca monta como éstas); si lo mejora, es una variante de autor (aunque el concepto de "mejoría" resulta relativo). El problema de esta clasificación, sostenida en una ética platónica de la copia (mejora de autor vs. mejora vs. error, donde a mayor distancia del autor aumenta la corrupción de la enmienda), es que por falta de evidencia autógrafa rara vez se puede superar ese idealismo pernicioso que atribuye al autor un control creativo absoluto sobre la obra literaria y ve cualquier otra variante como un tipo de acción deturpadora.

SEMEJANZAS Y DIFERENCIAS DE LAS VARIANTES DE IMPRENTA Y LAS VARIANTES DE AUTOR

Si el lugar común perdura es, en parte, porque tiene cierta razón respecto a las variantes de imprenta. Si volvemos sobre un impresor ilustre, Martín Nucio, es cierto que a la crítica se le ha dificultado determinar su grado de participación en la factura de los textos conservados en el Cancionero de Romances, en especial cuando afirma en su prólogo "yo hice toda diligencia porque hubiese las menos faltas que fuese posible y no me ha sido poco trabajo juntarlos y enmendar y añadir algunos que estaban imperfectos" (ff. A[2] r-v). Este "enmendar y añadir" permitió sospechar que los romances pasaron por el torno poético de Nucio, aunque hoy sabemos que esta suposición resulta infundada: como ha demostrado Mario Garvin al compulsar el texto de la edición de 1547-1548 con sus posibles fuentes impresas, los cambios a menudo son erratas o versos agregados para llenar la página o aclarar la situación narrativa ${ }^{15}$; al respecto, Garvin opina que "los criterios que guían esas correcciones ni siquiera son de carácter estético, sino que vienen condicionados por la necesidad editorial de ajustar los materiales disponibles al espacio tipográfico del cancionero" (ibid., p. 231). Una compulsa del texto de "Pésame de vos el conde..." en su fuente más probable, el Cancionero general de 1511, puede ofrecer un buen panorama del tipo de participación que tuvo Nucio y los oficiales de su taller (porque todo libro era, en la imprenta antigua, un trabajo colectivo):

15 Mario Garvin, op. cit., pp. 165-218. 
Cancionero general, 1511,

f. CXXXIr ${ }^{16}$

mas os valiera sobrino

delas damas no curar

q quiē mas haze por ellas

tal espera dalcāçar

q de muerte /o de perdido

ninguno puede escapar

q firmeza de mugeres

no puede mucho durar

q tales palabras tio

no las puedo comportar

quiero mas morir por ellas

q beuir sin las mirar
Cancionero de romances, 1547-1548, ff. 90v-91r

mas os valiera sobrino

delas damas no curar

que quien mas haze por ellas

tal espera de alcançar

que de muerto o de perdido

ninguno puede escapar

que firmeza de mugeres

no puede mucho durar

Que tales palabras tio

no las puedo comportar

quiero mas morir por ellas

que morir sin las mirar

Mario Garvin ha llamado ya la atención sobre dos cambios mayores y sobre el hecho de que, a pesar de haberse transmitido también por pliegos sueltos, en todos los casos la fuente preferida fue el Cancionero general (ibid., pp. 170-171 y n. 9). Sobre los cambios, se trata de lectiones faciliores que denuncian la composición descuidada del Cancionero de romances:

q de muertE / o de perdido que de muertO o de perdido

quiero mas morir por ellas quiero mas morir por ellas

q BEUIR sin las mirar que MORIR sin las mirar

Pese a estas erratas, el "enmendar y añadir" declarado por Martín Nucio está presente desde una perspectiva editorial. En el ejemplo seleccionado (y a lo largo de todo el Cancionero de romances ${ }^{16}$, Martín Nucio ha mejorado notablemente las fuentes de las cuales toma los textos al disminuir el número de abreviaturas en ellos. Tan sólo en esta breve selección se advierten nueve abreviaturas en el Cancionero general, contra ninguna del Cancionero de romances. El trabajo resulta tan pulcro al respecto que en todo el Cancionero de romances no se encuentran abreviaturas, fuera del signo tironiano o de otras desperdigadas aquí y allá en los títulos redactados en prosa ${ }^{17}$; Martín Nucio sólo se

16 Cito por Cancionero general recopilado por Hernando del Castillo (Valencia, 1511), ed. facs. por acuerdo de la Real Academia Española, con una introd. bibliográfica, índices y apéndices de A. Rodríguez-Moñino, Real Academia Española, Madrid, 1958 (consultado en línea en la Biblioteca Virtual Miguel de Cervantes, 8 de marzo de 2012).

17 Véanse ff. 42v, 103v, 136v, 144v, 169r, 177v, 215v, 236v, 238r, 272v, 275r; 
atreve a introducir abreviaturas en los textos cuando, por la inserción de una letra inicial en módulo mayor, es necesario compensar el espacio durante los tres primeros versos del romance, aunque sin que dicha afectación deje de resultar excepcional ${ }^{18}$. La erradicación de las abreviaturas es una forma de mejorar los textos que circulaban en los pliegos sueltos y se volverá una convención exitosa en los Romanceros, a juzgar por las ediciones subsecuentes del Cancionero de romances. El tema no era baladí para los impresores de la época; años antes, en su edición del Amadís (Venecia, 1533), Francisco Delicado presumía cómo la ausencia de abreviaturas era un logro editorial que contribuía a una lectura más placentera y efectiva:

II En la presente obra que aquí verás no ningunas abreuiaduras hallarás. Por dos causas: la una porque los caballeros que las leyeren o los que se las leen cuando ellos las oyen, no sea menester estar a deletrear. La segunda, porque como es enxemplo de caballería, no solamente españoles la tienen de leer, mas los latinos, italianos diversos, toscanos, tudescos, franceses, ingleses, húngaros y portogueses. Y, finalmente, todos aquellos a quien place el romance castellano por ser tan pelegrina lengua ${ }^{19}$.

Estas políticas editoriales eran comunes. Un siglo más tarde, el duque de Feria mandaba imprimir una nueva edición de las poesías de fray Luis de León con un tipo de letra más clara y de mayor volumen que el ejemplar preparado por Quevedo en $16^{\circ}$, según se lee en un prólogo anónimo que se daba "segunda vez a la luz común porque saliese mejor en mayor volumen, letra más clara, y impresión más esparcida, y porque la primera que remitieron a su excelencia de Madrid no se ajustaba por lo mal impresa con lo bueno de la materia"20. "Mal impresa", le-

en varios casos, "romāce", aunque no de forma sistemática, como en los ff. $65 \mathrm{v}, 72 \mathrm{r}, 78 \mathrm{r}, 90 \mathrm{v}$ y $91 \mathrm{r}$.

${ }_{18}$ Sólo se aprovecha este recurso en los ff. 91r, 91v, 100v, 129r, 131v, 132v, $134 \mathrm{v}, 137 \mathrm{v}, 139 \mathrm{r}, 157 \mathrm{v}, 158 \mathrm{v}, 163 \mathrm{v}, 166 \mathrm{v}, 169 \mathrm{r}, 184 \mathrm{v}, 186 \mathrm{v}, 199 \mathrm{v}, 226 \mathrm{r}, 229 \mathrm{v}, 231 \mathrm{v}$, $235 \mathrm{r}, 240 \mathrm{v}, 247 \mathrm{r}, 249 \mathrm{r}, 254 \mathrm{v}, 255 \mathrm{v}, 257 \mathrm{v}, 263 \mathrm{v}$ y $272 \mathrm{v}$.

19 Garci Rodríguez de Montalvo, Los quatro libros de Amadís d'gaula nueuamente impressos E hystoriados, Juan Antonio de Sabia, Venecia, 1533 (consultado en línea en la Biblioteca Virtual Miguel de Cervantes, 17 de agosto 2009; a partir del original de la Biblioteca Histórica de la Universidad de Valencia BH R-1/090, f. [AIv])

${ }^{20}$ Cito por José Manuel Blecua, “Introducción”, en fray Luis de León, Poesía completa, ed. de J.M. Blecua, Gredos, Madrid, 1990, p. 15. 
jos de ser una crítica a la calidad textual de los materiales que transmitía, debió referirse de forma exclusiva al módulo de la letra y al formato editorial del original. Las mejoras no habían de buscarse en estas ediciones en el terreno de sus lecciones, sino en el territorio más vasto de la bibliografía material, del mero soporte transmisor.

Aunque hoy nos parece que el impresor tenía soberanía absoluta sobre el texto que reproducía, es probable que en el fondo hubiera límites sobre los que no pasaría por ética o por comodidad. Ya entrado el siglo siguiente (1664), las prevenciones de Juan Caramuel al respecto arrojan algo de luz sobre los criterios que orientaban a los impresores, cuando se preguntaba si el impresor "debet [...] errores dictionis corrigere? Puta, soloecismos in prosa, exorbitantias quantitatum in metro?", respondía que sí, pues convenía tanto al autor de la obra como al estado: "Authoris, quia multi libri alias boni, ob errores Grammaticos vilipenduntur; Reipublicae, quia ita scientis juvenes doceri debent, ut non Grammaticam, Poeticamque dedoceantur"21. Pese a las libertades que parece conferir la recomendación, los límites de la intervención son precisos: solecismos e hipermetrías nada más (lo que apunta a la corrección gramatical y a la prosodia).

Pero nos engañaríamos si pensáramos que el autor, por ser quien era, tenía soberanía absoluta sobre la transmisión de su obra (y aquí estamos frente a otro lugar común cada vez más revisado por la crítica). La mejor y más completa ilustración al respecto se halla en la edición crítica de los romances de Góngora, preparada con el mayor esmero y mejores resultados por Antonio Carreira. Respecto a su papel como autor, sabemos que era un tanto descuidado, según cuenta su mismo editor:

En otro lugar hemos intentado explicar la falta de autógrafos poéticos en Góngora como prueba de que los borrones desaparecían una vez pasados a limpio. Y las copias desaparecían también, en manos del primer amigo que llegaba, con lo cual pocas probabilidades tenían de sufrir retoques. Se sabe que el poeta no conservaba sus poemas, aunque era bien consciente de cuáles de sus amigos los atesoraban. Es muy probable que salieran de su mano solo una vez pulidos, cuando, alcanzando cierto punto de perfección, no fuera posible introducir mejoras en ellos. La revisión que el poeta hizo del ms. Chacón hubo de ser, por circunstancias personales de

21 Syntagma de arte typographica, ed., trad. y glosa de P. Andrés Escapa, Instituto de Historia del Libro y de la Lectura, Salamanca, 2004, p. 182. 
Góngora, bastante irregular. Cuando en 1625 necesitó comprar un cartapacio de sus obras aparecido en Córdoba, no pudo restaurar versos perdidos y pasajes estragados en varios poemas, y, si en algún caso remozó la inspiración para completar o corregir con mayor acierto (romance núm. 50, por ejemplo), en otros más bien se limitó a restablecer lecturas primigenias, así como a recordar fechas y circunstancias, no sin esfuerzo, a juzgar por los errores: cosa lógica en un escritor escrupuloso, pero muy poco o nada profesional ${ }^{22}$.

Las observaciones de Carreira se confirman al revisar el minucioso aparato de variantes en su edición, donde puede advertirse que Góngora, como autor nominal y como responsable creativo de su obra, no quiso o no pudo controlar los sorprendentes descuidos (o colaboraciones, si se ve con cierto humor) de la imprenta. En el romance, "Ciego que apuntas y atinas..." (vv. 1-4, 21-24, 27-28, 41-44), de 1580, según el texto crítico de Antonio Carreira, pueden encontrarse las siguientes variantes en los impresos de la época, desde 1591 hasta 1634:

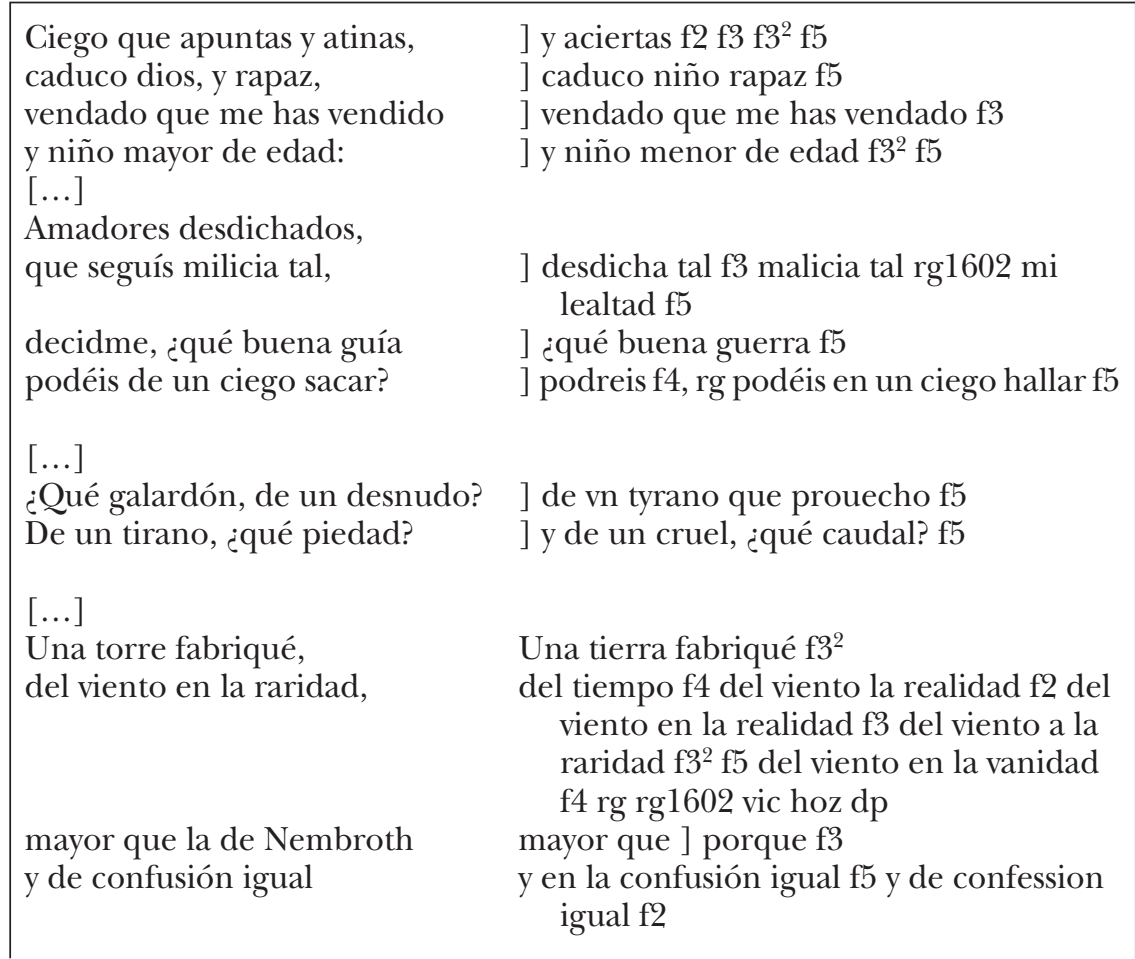

22 Antonio Carreira, "Introducción" a Luis de Góngora, Romances, ed. crítica de A. Carreira, Quaderns Crema, Barcelona, 1998, t. 1, pp. 27-28. 
f2: Flor de varios romances nuevos. Primera y segunda parte, Barcelona, 1591; f3: Flor de varios romances nuevos. Primera y segunda y tercera parte, Madrid, 1593 y Flor de varios y nuevos romances. Primera y segunda parte [...] añadiose aora nuevamente la terçera parte, Valencia, 1593. Hay dos versiones del Romance; las variantes de la segunda versión bajo $\mathrm{f3}^{2}$; f4: Qvarta y quinta parte de Flor de romances, Burgos, 1592; f5: Ramillete de flores [...] quarta [...] parte de Flor de romances nueuos, Lisboa, 1593; rg: Romancero general, en que se contienen todos los romances que andan impressos en las nueue partes de Romanceros, Madrid, 1600; rg1602: Romancero general, en que se contienen todos los romances que andan impressos en las nueue partes de Romanceros, Medina del Campo, 1602; vic: Obras en verso del Homero español que recogió Juan López de Vicuña, Madrid, 1627; hoz: Todas las obras de don Luis de Góngora en varios poemas, Madrid, 1633; dp: Delicias del parnaso, Barcelona, 1634.

A simple vista se advierte la soberanía absoluta de la lectio facilior y/o errata en distintos niveles, fuera del control de su autor: en la Tercera parte de Flor de varios romances se arruina la paronomasia vendado/vendido por una repetitio descuidada (clara errata) y el oxímoron "niño mayor de edad" se pierde cuando se sustituye por un "niño menor de edad" (también así en la Quarta parte); la lectio facilior en la cuarta parte resulta consecuente con la sustitución previa, donde el "caduco dios, y rapaz", también un tipo de oxímoron que une al dios anciano con el infante se transforma en redundancia, "caduco niño rapaz", cuando el "niño" es "niño" y "rapaz". La sustitución no deja de ser apresurada y poda alguna gracia al verso original, con varios sentidos asociados: el "caduco dios" apunta al hacer experimentado del Amor como un dios de mucha edad (pues la primera acepción de "caduco" en el Diccionario de Autoridades es "decrépito y muy anciano"), pero también a su inconstancia (en el mismo diccionario, "por translación significa todo lo que es poco estable, perecedero y cercano a caerse y acabarse"); lo mismo sucede con "rapaz", "muchacho pequeño de edad" usado como sustantivo, pero con un valor muy diferente en su uso como adjetivo: "el que tiene inclinación o está enviciado en el robo, hurto o rapiña”. El verso 22 debió plantear algún problema de sentido a los componedores por la presencia del cultismo milicia, de poco uso fuera de un ambiente latinista en las obras de Alfonso de Palencia, Juan de Lucena, Fernández de Heredia, Fernández de Oviedo, de Jerónimo de Urrea y otros ingenios, o del terreno especializado de la literatura militar de la época, como la Plática manual de artillería de Luis Collado de 1592; también es relativamente frecuente en otros autores como Quevedo, Lope en 
sus Rimas sacras, Juan de Jáuregui o Góngora, pero resulta escaso, por el contrario, en el Romancero, donde de modo peregrino se encuentra un "espejo de la milicia" en el romance "Tan celosa está Adalifa" del Romancero general y otro "en la milicia perito" en Ginés Pérez de Hita ${ }^{23}$. Así las cosas, algún componedor, dejándose llevar por la grafía, compuso "malicia" (Romancero general, 1602) y en la Quarta parte se recompusieron los dos versos y se sustituyó "milicia", pero se mantuvo el tono bélico, de modo que "Amadores desdichados / que seguís milicia tal, / decidme, ¿qué buena guía / podéis de un ciego sacar?”, quedó ahí como "Amadores desdichados / que seguís mi lealtad /, decidme ¿qué buena guerra / podéis en un ciego hallar?”, lo que revierte los valores originales sobre un guía malo, por ciego, y lo convierte en un ciego desvalido y pésimo contrincante para librar una buena guerra (a contracorriente de todo el romance). Novedades (o erratas) de este tipo son frecuentes en el Ramillete de flores [...] quarta parte, como cuando la commutatio “¿Qué galardón, de un desnudo? / De un tirano, ¿qué piedad?" se desestima (o simplemente no se advierte) y se transforma en una simple isotaxia "de vn tyrano, ¿que prouecho? / y de un cruel, ¿qué caudal?”. Por supuesto, los cambios más abundantes son trivializaciones léxicas: la "torre" se convierte en "tierra"; el "viento", en "tiempo"; la "raridad", presente en autores escogidos como Cervantes, Gracián, Sigüenza y Góngora, se sustituye por términos más comunes, pero inexactos, como la "realidad" o la "vanidad"; la "confusión" original de esta torre será luego "confession".

¿Podemos hablar de variantes de autor sin más, ante tanto disparate? Difícilmente, en especial cuando en las compilaciones de romances se seguía la tradición del anonimato (como pasa con este romance de Góngora en las Flores de romances y en el Romancero general), lo que termina por empañar las funciones características del autor en esta cadena de transmisión. Para los Siglos de Oro, una generosa distancia entre el producto artístico y la función del autor era entendida y asumida por los propios poetas sin llegar nunca a rasgarse las vestiduras; el desprendimiento con el que Góngora trata sus composiciones era un síntoma general, que padecería nuestra poesía desde Garcilaso (cuya obra quizá no se hubiera salvado de no quedar con-

${ }^{23}$ Véase el Banco de datos del Corpus Diacrónico del Español, Real Academia Española (consultado en línea el 9 de marzo de 2012, s.v. "milicia" y "militia"). 
servada por Boscán como libro cuarto de sus obras) y atraviesa el mundo cultural de los Siglos de Oro, desde las obras de Fernando de Herrera, muy probablemente intervenidas por Francisco Pacheco ${ }^{24}$ o la poesía lírica de Quevedo, sobre la que pesa también la sospecha de la intervención de González de Salas y de Pedro Aldrete Quevedo y Villegas, a pesar de un buen número de correcciones que debieron pertenecer al autor ${ }^{25}$; de Quevedo, sabemos que llevó a la imprenta el proyecto de editar la obra poética de fray Luis de León, pero también nos consta que se limitó a enviar el códice de Sarmiento sin revisar siquiera las pruebas, lo que explica dos versiones de la Oda IV, erratas numerosas y varias omisiones ${ }^{26}$. La conservación de manuscritos autógrafos de la época, con enmiendas y numerosas banderillas bajo las cuales se esconden para siempre versiones primitivas corregidas con meticulosidad por el autor, son una rareza, como sucede con las églogas de Juan de la Cueva ${ }^{27}$.

Ante este panorama, resulta un hecho que nuestra clasificación de variantes de autor se sostiene de nuevo en el idealismo platónico de considerar la variante de más calidad como una variante atribuible a un autor y la de menor calidad al proceso mecánico de composición.

\section{PATRONES DE VARIACión DEL TEXTO ANÓNiMO}

\section{AL TEXTO DE AUTOR}

Las variantes, con o sin intervención de un autor nominal, proliferaron y enriquecieron el Romancero, pero su asistematicidad y la nómina de posibles responsables (autor, impresor, compilador, corrector, transmisor oral) nos han impedido sacar provecho de este filón, pues resulta incluso difícil aspirar a una tipología. Pesan mucho, también, nuestros prejuicios, pues ante la sospecha de intervenciones anónimas que podrían pro-

${ }^{24}$ Un cuidadoso estado de la cuestión en Cristóbal Cuevas, "Introducción" a Fernando de Herrera, Poesía castellana original completa, ed. de C. Cuevas, Cátedra, Madrid, 1985, pp. 87-102.

${ }^{25}$ José Manuel Blecua, "Introducción” a Obra poética, ed. de J.M. Blecua, Castalia, Madrid, 1999, t. 1, pp. xi-xxxviii.

${ }^{26}$ J.M. BlecuA, "Introducción" a fray Luis de León, op. cit., p. 15.

27 José Cebrián, "Unas Églogas a la luz de la ecdótica", En la Edad de Oro, estudios de ecdótica y crítica literaria, El Colegio de México, México, 1999, pp. 57-82. 
venir de la tradición oral, de la musa bárbara del componedor o ser una simple errata, estas variantes suelen desestimarse casi de forma automática. Si aspiramos nada más a la constitución de un texto crítico, resulta fácil denostar estas variantes que no están ligadas al nombre de un Góngora o un Quevedo por su natural pobreza como lectiones faciliores, pero si nos interesa comprender el rico universo de variación dentro del universo mayor de la imprenta, tenemos por fuerza que atender otras variantes de menor prestigio, procedentes en muchos casos de una inspiración anónima, pero inmersas en un proceso de recepción donde existieron y tuvieron un sentido.

Quizá habría que empezar por llamar la atención sobre el impresor como un profesional de la transmisión impresa y no un mero técnico que inserta erratas por gusto. En el caso de una variante como "Marinero de Tarpeya" por el correcto "Mira Nero de Tarpeya", originada para la crítica en la tradición oral, Mario Garvin señala que "si el romancero se concibe como un género impreso, la variante mencionada sigue siendo uno de los más evidentes y ridículos errores de su historia, pero a mi juicio debería eliminarse del texto y, a lo sumo, dedicarle una nota más o menos erudita en donde se comente la confusión y la incultura del transcriptor" (op. cit., p. 99); pues el transcriptor es Cervantes y lo que ha escrito de "Marinero de Tarpeya" no lo ha puesto por ignorancia ni porque lo haya escuchado cantar en la calle de un transmisor turulato, sino con una intención burlesca, al final del Rinconete y Cortadillo, cuando el narrador celebra que sea Rinconete, "aunque muchacho, de muy buen entendimiento", lo que ilustra al apuntar que, como "sabía algo de buen lenguaje", "dábale gran risa pensar en los vocablos que había oído a Monipodio y a los demás de su compañía", como "cuando la Cariharta dijo que era Repolido como un Marinero de Tarpeya y un Tigre de Ocaña, por decir Hircania, con otras mil impertinencias"28. Ambos disparates vuelven a aparecer en otras ocasiones ${ }^{29}$, lo que prueba la naturaleza intencional del barbarismo. La lección, por supues-

28 Miguel de Cervantes, Novelas ejemplares, ed. de H. Sieber, Cátedra, Madrid, 1985, t. 1, pp. 239-240.

${ }^{29}$ Un poco antes, cuando la Cariharta le pide a Monipodio que no le abra la puerta a Repolido, "a ese marinero de Tarpeya, a ese tigre de Ocaña" (ibid., p. 227); aparece de nuevo en La Gitanilla, cuando Preciosa canta su suerte a la tenienta por un humilde dedal de plata y la describe con metáforas jocosas como la del "tigre de Ocaña" (ibid., p. 79). 
to, no fue provocada por interferencia de ninguno de los pliegos sueltos conservados, pues ni en el más humilde y errático se ha conservado esta lección, ni por ningún cancionero impreso $^{30}$. Sin duda se trata nada más de un chiste erudito. Augusto Monterroso recuerda que hace años, en el café Triana en México, Raimundo Lida contaba sobre aquellos lectores imaginativos que entendían "El dulce lamentar de dos pastores" de Garcilaso como "El dulce lamen tarde dos pastores" 31 ; variación jocosa y, en el fondo, ni error de impresor ni de transmisor turulato, simple anécdota erudita. En ninguno de ambos casos, ningún impresor, en su sano juicio, hubiera caído en la trampa; en primer lugar, porque la errata inicial supondría el fracaso comercial de la tirada y una mancha a su expediente comercial delante de los posibles compradores; después, porque los impresores tampoco eran tontos.

En el fondo, la intervención de un impresor puede convertirse en una fuente de sentidos nuevos para el lector si se tiene el ánimo para colaborar con la nueva lección. En el caso comentado del romance "Ciego que apuntas y atinas...", las variantes del Ramillete de flores [...] quarta parte nos comprueban la incuria del compilador/impresor desde la perspectiva de la estética gongorista, al haber pasado por alto la secuencia de cinco commutationes (A sustantivo + B complemento de origen encabezado por preposición $d e$ ), las últimas cuatro distribuidas en espejo en el manuscrito Chacón y otras fuentes:

$\begin{array}{ll}\begin{array}{l}\text { Amadores desdichados, } \\ \text { que seguís milicia tal, } \\ \text { decidme, ¿qué buena guía } \\ \text { podéis de un ciego sacar? }\end{array} & \mathrm{A}+ \\ ----- & \mathrm{B} \\ \text { De un pájaro, ¿qué firmeza? } & \mathrm{B}+\mathrm{A} \\ \text { ¿Qué esperanza, de un rapaz? } & \mathrm{A}+\mathrm{B} \\ \text { ¿Qué galardón, de un desnudo? } & \mathrm{A}+\mathrm{B} \\ \text { De un tirano, ¿qué piedad? } & \mathrm{B}+\mathrm{A}\end{array}$

30 Paloma Díaz-Mas, "Sobre la fortuna del romance 'Mira Nero de Tarpeya'”, en Symbolae Lvdovico Mitxelena Septuagenario Oblatae, ed. de J.L. Melena, Universidad del País Vasco, Vitoria, 1985, t. 1, pp. 795-798.

31 Augusto Monterroso, "Las almas en pena", La letra e, Era, México, 2003, p. 64. 
La secuencia termina en Ramillete de flores:
De un pájaro, ¿qué firmeza?
$\mathrm{B}+\mathrm{A}$
¿Qué esperanza, de un rapaz?
$\mathrm{A}+\mathrm{B}$
de vn tyrano que prouecho
$\mathrm{B}+\mathrm{A}$
y de un cruel, ¿qué caudal?
$\mathrm{B}+\mathrm{A}$.

Se pierden, sin duda, las sutiles y armónicas correspondencias creadas por Góngora, pero el cambio mejora el texto en cierta forma: restituye el patrón de sintaxis más complejo $(\mathrm{B}+\mathrm{A})$ y transforma la commutatio en una isotaxia más simple y que no concuerda mal con el estilo de Góngora, generalmente en clave graciosa:

En la botica otras veces me daba muy buenas zurras, del triunfo, con el alcalde, del ajedrez, con el cura

$\mathrm{B}+\mathrm{A}$

$\mathrm{B}+\mathrm{A}^{32}$

Violante, que, un tiempo, fuiste pelota de mi trinquete, de mis botones, ojal, $\mathrm{y}$ de mis cintas, ojete

$\mathrm{A}+\mathrm{B}$

$\mathrm{B}+\mathrm{A}$

$\mathrm{B}+\mathrm{A}^{33}$

Efecto improviso es,

no de los años diuturno,

sino de un niño, en lo flaco,

$\mathrm{B}+\mathrm{A}$

y de un dios, en lo oportuno:

$\mathrm{B}+\mathrm{A}$

pared que nació conmigo,

del Amor sólo el estudio

$\mathrm{B}+\mathrm{A}$

no la fuerza de la edad,

$\mathrm{A}+\mathrm{B}$ desatar sus piedras pudo ${ }^{34}$.

Como se advierte en los ejemplos, el patrón B + A no resulta raro y sí lo es la organización conmutacional de "Ciego que apuntas y atinas...”. En otros casos, mucho menos atractivos, se presentan paralelismos de acuerdo con el esquema sin hipérbaton $(A+B)$ :

32 “Ahora que estoy de espacio...”, en Romances, ed. cit., núm. 25, wv. 29-32.

33 "Tendiendo sus blancos paños...", en ibid., núm. 37, vv. 57-60.

34 "La ciudad de Babilonia...", en ibid., núm. 74, vv. 193-200. 
Dicen que se los dio en ferias, tres o cuatro días antes, el Píramo de su aldea, $\quad \mathrm{A}+\mathrm{B}$ el sobrino del alcalde. $\quad \mathrm{A}+\mathrm{B}^{35}$

cuando sean vuestras aguas munición de cien mil tiros, $\mathrm{A}+\mathrm{B}$ admiración de los ojos $\mathrm{A}+\mathrm{B}$ y batería de castillos $\mathrm{A}+\mathrm{B}^{36}$.

Para un público acostumbrado al Romancero viejo y erudito, estos últimos esquemas continuaban de forma más natural lo que habían visto antes en Lorenzo de Sepúlveda o en el $R_{0}$ mancero del Cid de Juan de Escobar, del tipo:

Quítate Rodrigo allá, quítateme de allá diablo, que tienes el gesto de hombre y los hechos de León bravo

$$
\begin{aligned}
& A+B \\
& A+B^{37}
\end{aligned}
$$

Mentirosos adalides que de las vidas ajenas, guisáis platos para el gusto de muchas sordas orejas, fidalgos de Villalón caballeros de Valduerna, homes buenos de Villalda, y Christianos de Sansueña.

$\mathrm{B}$

$\mathrm{A}+$

$\mathrm{A}+\mathrm{B}$

$\mathrm{A}+\mathrm{B}$

$\mathrm{A}+\mathrm{B}$

$\mathrm{A}+\mathrm{B}^{38}$.

La versión de "Ciego que apuntas y atinas..." del Ramillete de flores [...] quarta parte está plagada de errores de lectura y otras trivializaciones desde la perspectiva de quien desee restituir las lecciones auténticas del romance gongorino, pero tampoco falta sentido a los "errores" del Ramillete en la tradición del Romancero, pues con toda seguridad la trivialización del editor o del componedor sería bien recibida por un público no muy exigente para el que una lectio facilior podría tener el mismo sentido que para el editor, quien ha cometido el error no por voluntad, sino por incomprensión de la intención primige-

35 "En el baile del ejido...", en ibid., núm. 61, vv. 5-8.

36 “A vos digo, señor Tajo...", en ibid., núm. 35, vv. 33-36.

37 Sepúlveda, ed. cit., p. 301.

38 JUAN DE Escobar, ed. cit., p. 175. 
nia del autor. Poner al impresor, corrector o componedor, del lado del público era en cierta forma más natural que ponerlo al lado de un ingenio privilegiado y rara avis de su tiempo como Góngora. Un verso como "vendado que me has vendido" pierde algo de su sentido fuera de un contexto venial (¿"vendido" a quién?), pero se vuelve un chiste más obvio cuando se restituye al contexto del Amor ciego (que es por donde ha empezado el romance) con "vendado que me has vendado", pues un ciego contagia a otro su ceguera, si esto es posible. "Niño menor de edad" arruina el oxímoron de "niño mayor de edad", pero subraya hiperbólicamente que se trata de un Amor infantil e irresponsable, en consonancia con el cambio de "caduco niño rapaz" en lugar de "caduco dios, y rapaz" (y "caduco niño" conserva la gracia del oxímoron con menos rodeos). Los impresores, conocedores del público para el cual editaban, no encontraron sentido al cultismo "milicia" y lo sustituyeron de acuerdo con el contexto (recordemos que "Amadores desdichados / que seguís milicia tal, / decidme, ¿qué buena guía / podéis de un ciego sacar?", se transformó en "Amadores desdichados / que seguís mi lealtad, /, decidme ¿qué buena guerra / podéis en un ciego hallar?"); la "raridad", también poco frecuente, se sustituye en aras de mejorar la comprensión por la "realidad" o la "vanidad" (aunque, para ser sinceros, ni en la versión de Góngora ni en la de las Flores puede sacarse el sentido en claro sin algún esfuerzo); la "torre" por la "tierra" y la "confusión" original de esta torre será luego "confession", lo que demuestra que los impresores no entendieron, pero al menos se esforzaron por buscar formas léxicas que resultasen más familiares a sus lectores.

El hecho de que las sustituciones no lesionen la res metrica de cada octosílabo me parece una prueba irrefutable de la validez coetánea de las lecciones innovadoras. En el octosílabo de cierre, incluso la prosodia de la sustitución sigue un patrón culto, pues "cruel" ha de pronunciarse bisílabo para completar el octosílabo (“ý-deun-cru-él-¿qué-cau-dál?”, prosodia latinizante heredada de "crudelis"), aunque Góngora lo ha usado sin atender a ello en sus propios romances, donde se encuentra una pronunciación monosílaba y bisílaba indistintamente ${ }^{39}$. Parece

39 Prosodia bisílaba: "tan cruel, que en vn prouiso" (ed. cit., núm. 100, v. 18); "passe este cruel planeta" (núm. 167, v. 13) y "piadoso hierro cruel" (1615, Letrillas, núm. 47, v. 80). Prosodia monosílaba: "por los bosques, cruel 
más artística y correcta la lección bisílaba, "cru-el", con su tufillo de prosodia latinizante, pero a decir verdad, la lección monosílaba es la menos frecuente, la difficilior, como lo demuestra una revisión de sus ocurrencias en la lírica romanceril del Corpus diacrónico del español ${ }^{40}$. En todo caso, los criterios de inserción de estas sustituciones resultan manifiestos: sin importar la causa ni la orientación de la borradura y de la sustitución, en el llenado se atiende a la eufonía y a un sentido contextual inmediato que, al menos desde una perspectiva individual, mejora la lección primigenia desde la perspectiva del circuito de comunicación entre el impresor-corrector y el consumidor final, allanando el camino al no culterano.

Si revisamos ejercicios literarios manuscritos, aquéllos que ni pasaron a la imprenta ni circularon en impresos, se advierte que quienes leían, recopilaban, recitaban y escribían poesía, no tenían reparo en intervenir en el proceso de transmisión bajo estas mismas pautas de respeto a la res metrica y a un propósito de mejoras, vistas desde una perspectiva personal. $\mathrm{Si}$ volvemos a los romances de tema histórico, el episodio de "Afuera, afuera, Rodrigo..." dio, entre 1585-1590, varios vástagos en el dilatado cauce de la transmisión manuscrita cuyas variantes pueden ilustrar bien las convenciones de sustitución por miembros de una comunidad cultural que, sin perseguir la meta del impreso, sí están interesados en contribuir con versos e ideas propias a la tradición. El romance es "Alrededor de Zamora..." 41 :

verdugo" (núm. 13, v. 19); "mas déxame aora, cruel” (núm. 143, v. 59) y "Mas, ay, que tirano cruel” (núm. 235, v. 37).

40 Véase el Banco de datos del Corpus Diacrónico del Español, Real Academia Española (consultado en línea el 15 de marzo de 2012, s.v. “cruel”).

41 Transcribo los distintos testimonios manuscritos a partir de sus ediciones recientes; atribuyo, por comodidad para este trabajo, siglas consecutivas para identificar los testimonios (A, B, C, D, E). Respeto, en cada caso, los criterios de los diferentes editores, cuyos créditos aparecen a pie de página. Uso líneas de puntos para indicar omisiones de versos completos (o adiciones en los otros testimonios), con el propósito de mantener siempre a la vista del lector las sustituciones de cada testimonio verso a verso. Todos los testimonios de la tradición, glosas incluidas, están detallados y recogidos en PAOLA LASKARIS, El Romancero del cerco de Zamora en la tradición impresa y manuscrita (siglos XV-XVII), Universidad, Málaga, 2006, pp. 165-171. 


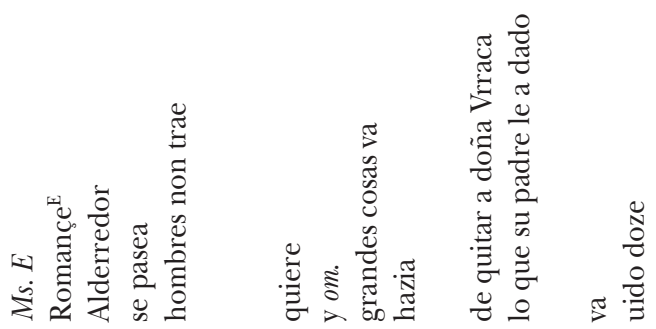

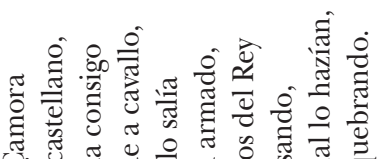
ن.

ชั

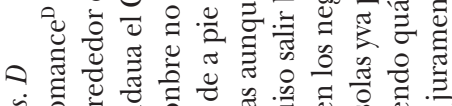

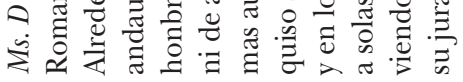
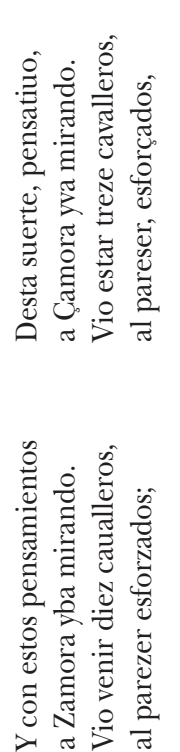

:ृ

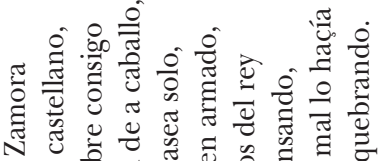
ษ

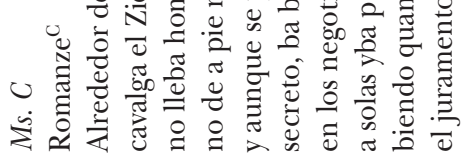

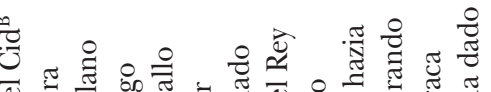

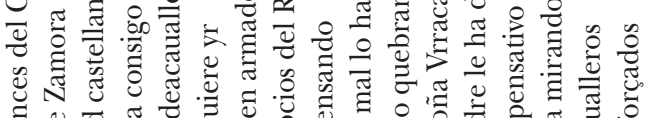
苂 苛

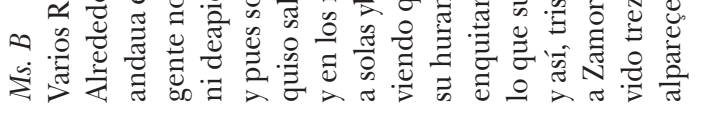

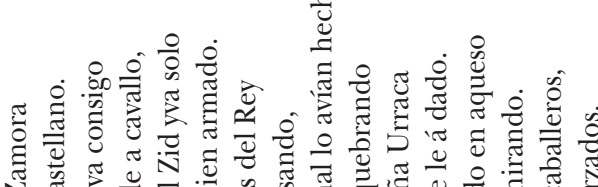

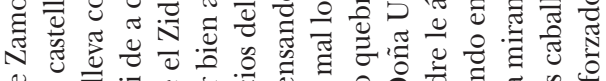

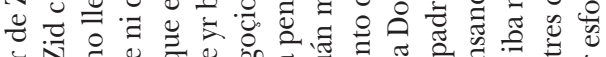

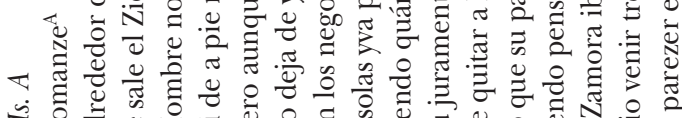

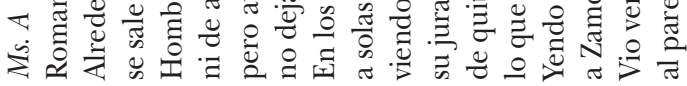

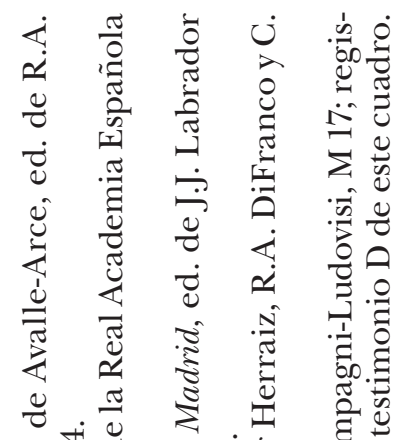

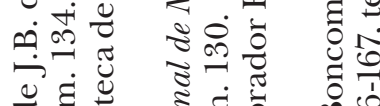

ช.

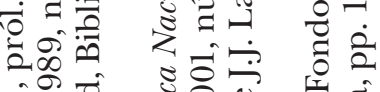

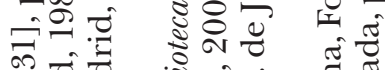

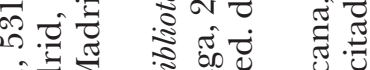

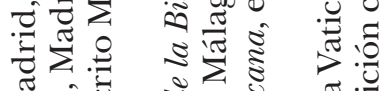

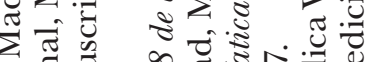

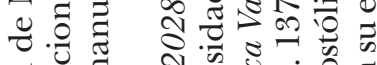

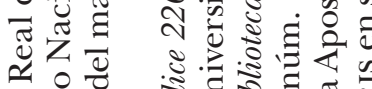

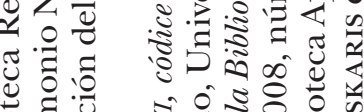
을.

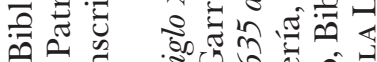

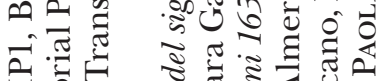
司氙 Z.ت己

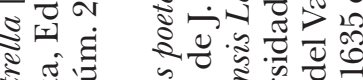
సี.

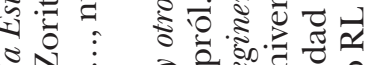
- N $\vdots$ 2

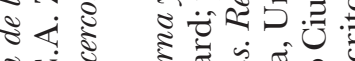
ఏ઼

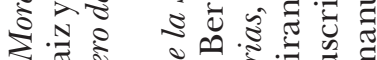

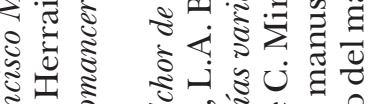
吾范

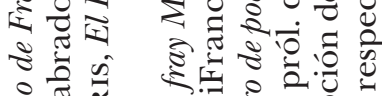
원

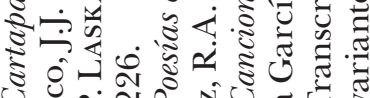
ช

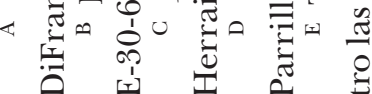




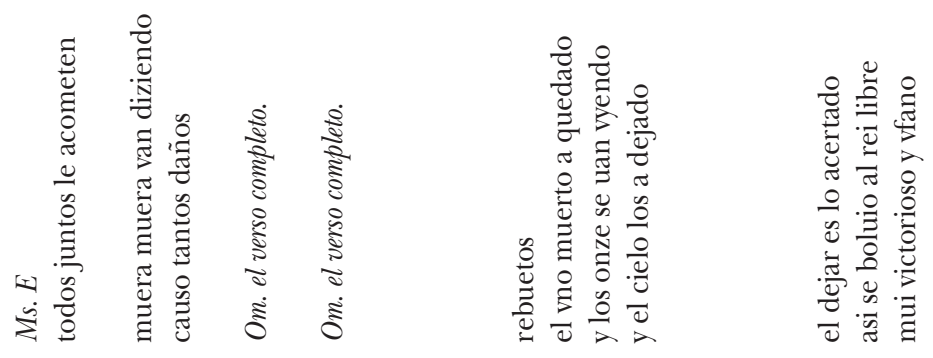

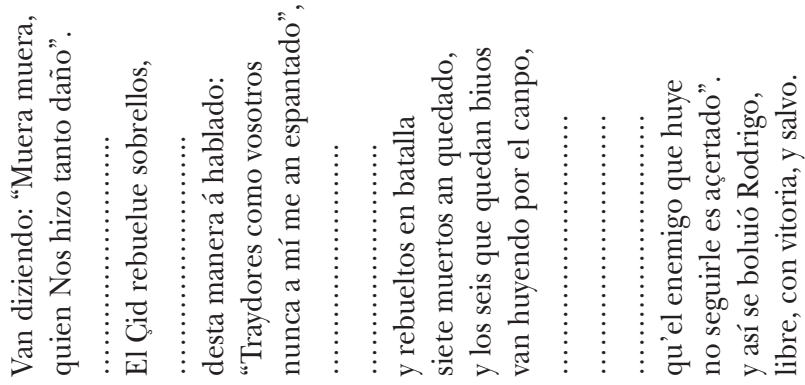

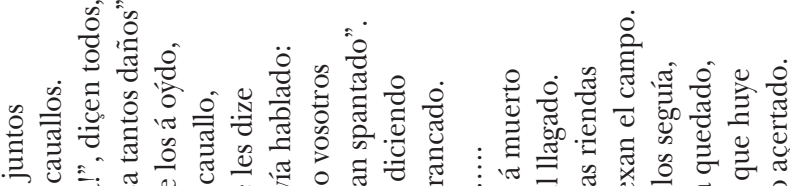

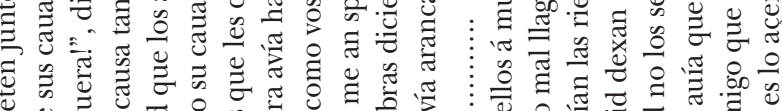
घ

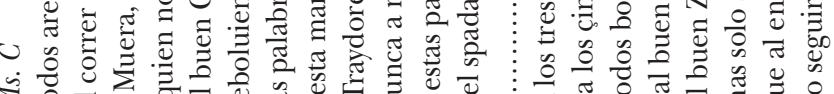

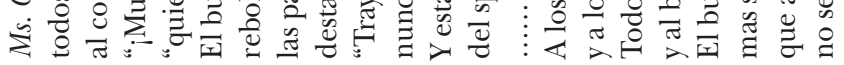

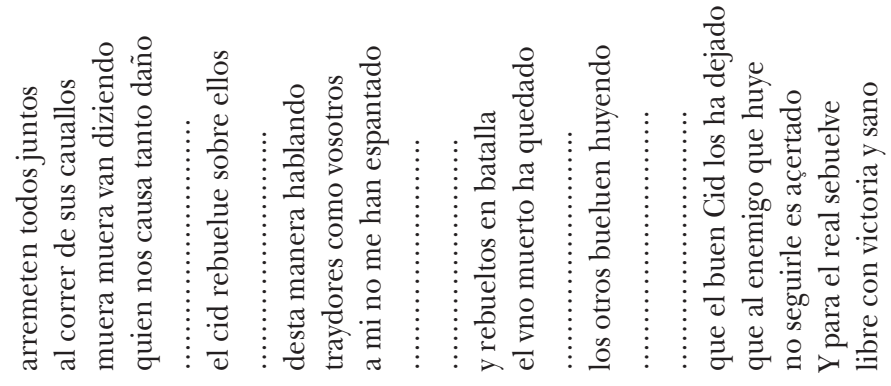

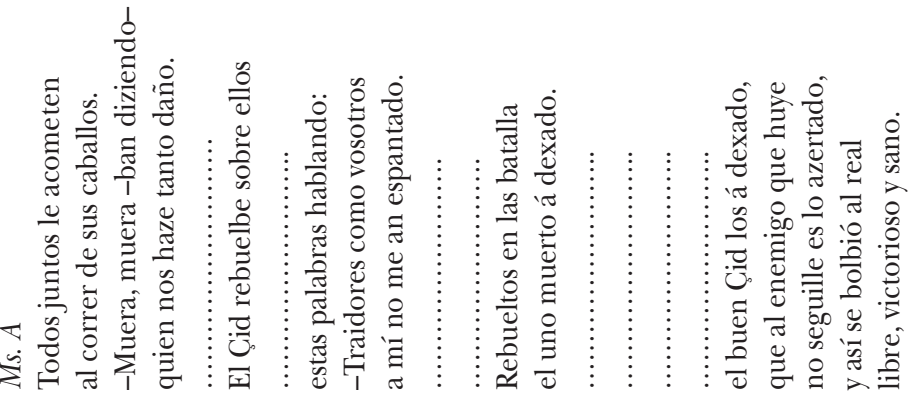


El romance no se conoce por fuentes impresas, aunque la parcial estabilidad entre las fuentes manuscritas podría sugerir la existencia de un pliego suelto no conservado. Como ha señalado Carola Reig, "corresponde al grupo de romances artificiosos de la primera época, que imitan el tono de los tradicionales. Desarrolla brevemente el episodio del Cid frente a las murallas de Zamora, pero complicando y adornando la situación"42. En el aspecto narrativo, se sitúa luego de la encomienda del rey Sancho de solicitar a Urraca la entrega de Zamora, la entrevista con Urraca en donde el Cid habrá de ser despedido y quedará prendado de la zamorana al mismo tiempo, y el regaño de don Sancho de "Enoxado está don Sancho..."43.

Ninguno de los cinco textos tiene coincidencias significativas entre sí, aunque resulta evidente que todos proceden de una fuente común, oral o escrita. Los testimonios A y C son los más completos en cuanto a extensión, pero no podemos perder de vista que sólo A, B y E transmiten su material sin censurar la acción del rey don Sancho, quien rompe una promesa al "quitar a Doña Urraca / lo que su padre la a dado"; fuera de estos rasgos generales, en los cinco testimonios la variación es abundante, sin poder identificar variantes de copia que indiquen una cadena de transmisión manuscrita posible (lo que, por otra parte, permite suponer un buen número de versiones intermedias perdidas hoy).

En cada caso, los diferentes compiladores corrigen el modelo y dan rienda suelta a su musa al aportar sus mejoras (con lo que, en el fondo, se transforman en coautores de este cadáver exquisito romanceril). Pese a las diferencias, todos coinciden en considerar que la enmienda o variante debe realizarse a partir de unidades cortas identificables como el léxico, el sintagma y, la de mayor extensión, el verso (y cuando más de uno, para respetar las rimas en unidades superiores como el parea-

42 El cantar de Sancho II y Cerco de Zamora, Aguirre, Madrid, 1947, p. 149 (Anejos de la Revista de Filología Española, 37).

${ }^{43}$ La circulación manuscrita del romance no exime a los autores de un conocimiento del acervo impreso, continuado aquí en cierta forma para llenar el vacío en los impresos. La imagen de un Cid solitario que va pensando en los negocios del rey recuerda, por ejemplo, el romance nuevo de "Pensativo estaba el Cid...", donde Rodrigo discurre sobre las consecuencias de vengar la afrenta de su padre, presente en varias fuentes impresas como la Flor tercera (Lisboa, 1591, ff. 238v-240r), Flor quinta de romances (Lisboa, 1593, f. 145v) y en el Romancero general (Madrid, 1600, ff. 75v-76r). 
do), para no modificar de modo radical la historia ni orientarla por nuevos derroteros (para eso, por ejemplo, estaba la glosa, la continuación o la contrahechura). Sobre el número de enemigos del Cid, fluctuante en las cinco versiones, los diferentes coautores vuelven una y otra vez para realizar los ajustes necesarios al número de enemigos. Si atendemos al orden cronológico propuesto por Paola Laskaris para los cinco testimonios (a partir del estudio de los testimonios por sus editores), pueden comprobarse coincidencias parciales entre sus fechas, pero ninguna que nos permita advertir un orden temporal en el número creciente de enemigos (por lo que resultaría difícil afirmar que sus diferentes coautores o compiladores conocieron escalonadamente las versiones y cada uno sobrepujó en su nueva versión el número de enemigos). Parece posible, sin duda, ver en A una versión primitiva, con sólo tres caballeros, pero las cifras se elevan luego sin orden hasta trece, pasando por diez y doce $^{44}$. Esta caprichosa escalada de enemigos permite, sin embargo, advertir las dificultades de cada compilador o coautor al insertar su variante respecto al número de oponentes y encontrar, versos después, que en el romance mismo se precisa el número de enemigos caídos; esta reaparición del tema invita en algún caso a ajustar las otras ocurrencias a la cifra propuesta, aunque no resulta prioritario:

A: Vio venir tres caballeros

[...]

Rebueltos en las batalla

el uno muerto á dexado.

B: vido treze caualleros

$[\ldots]$

y rebueltos en batalla

el vno muerto ha quedado

los otros bueluen huyendo

C: Vio venir diez caualleros

$[\ldots]$

A los tres dellos á muerto

y a los çinco mal llagado

${ }^{44}$ Vio venir tres caballeros, 1585 A; Vio estar treze cavalleros, 1586 D; Vio venir diez caualleros, 1587-1589 C; uido doze, s. XVII E; vido treze caualleros, s. XVII B. 
D: Vio estar treze cavalleros

$[\ldots]$

siete muertos an quedado

y los seis que quedan biuos

van huyendo por el canpo

E: uido doze cavalleros

[...]

el vno muerto a quedado

y los onze se uan vyendo

y el cielo los a dejado.

Los ajustes ofrecen al menos tres patrones de acción: 1) la muerte de un caballero incita a huir a los demás, presentados como un colectivo sin número determinado por lo que no se requieren cambios importantes después (testimonios A y B); 2) el compilador o coautor busca que los números coincidan (testimonios D y E) ; 3) por error, el número de caballeros inicial no coincide con el número final (testimonio $\mathrm{C}$ ). Las sustituciones ilustran la naturaleza de los cambios: el error, no advertido en el testimonio $\mathrm{C}$, sugiere que el texto se corrigió durante el mismo proceso de copia (o autorrecitado, de haber tenido una fuente oral) sin que hubiera una lectura de revisión.

Quizá para evitar las consecuencias de variantes como éstas, en las que sólo se complican las cosas por la falta de previsión sobre el rumbo narrativo que tomaría la historia, una buena parte de las sustituciones se hace sobre un eje localizado de selección léxico (palabras de sentido y métrica semejante), sintagmático (sintagmas de morfología y sentidos semejantes) o esticomítico (versos con contenidos semejantes), con lo que se minimiza el efecto no deseado de cambios narrativos en secciones posteriores y otras afectaciones que requerirían variantes adicionales. Estas sustituciones se realizan teniendo en cuenta un segundo patrón de cambios, que puede ser silábico (se respeta la densidad silábica, pero no la acentuación) o prosódico (se respeta densidad silábica y acentuación), de acuerdo con la siguiente tipología en orden de complejidad creciente:

1. Adición u omisión de conjunciones expletivas que forman diptongo por la vocal inicial de la siguiente palabra o final de la previa, sin cambio del patrón prosódico:

En los negoçios del Rey A $y$ en los negocios del Rey B 
en los negotios del rey $\mathrm{C}$

y en los negoçios del Rey D

en los negoçios del Rey E

2. Sustituciones léxicas sobre patrones prosódicos (se respeta la densidad y perfil tónico de sílabas de la palabra sustituida) o silábicos (con la misma densidad silábica puede haber licencias acentuales, debido a la flexibilidad del octosílabo, como se aprecia en el testimonio E según el esquema métrico):

quien nos haze tanto daño A quien nos causa tanto daño B quien nos causa tantos daños $\mathrm{C}$ quien Nos hizo tanto daño" D quien nos causó tantos daños $\mathrm{E}$
1.3.5.7 Melódico pleno ${ }^{45}$

1.3.5.7 Melódico pleno

1.3.5.7 Melódico pleno

1.3.5.7 Melódico pleno

1.4.7 Dactílico

3. Sustituciones sobre patrones semánticos, morfológicos y prosódicos (con licencias en el perfil tónico, como en el anterior, en E):

se sale el Zid castellano A

andaua el cid castellano B

cavalga el Zid castellano C

andaua el Cid castellano D

se pasea el Cid castellano E
2.4.7 Heroico puro

2.4.7 Heroico puro

2.4.7 Heroico puro

2.4.7 Heroico puro

3.7 Melódico puro

4. Sustituciones sobre patrones semánticos y prosódicos, pero con cambios morfológicos (en este caso, entre las variadas perífrasis verbales de $\mathrm{B}, \mathrm{D}, \mathrm{E}$, la perífrasis con negación de $\mathrm{A}$ y un adjetivo en $\mathrm{C}$ con cambios en el perfil tónico):

no deja de yr bien armado A

quiso salir bien armado B quiso salir bien armado D quiere salir bien armado $\mathrm{E}$ secreto, ba bien armado $\mathrm{C}$
1.4.7 Dactílico

1.4.7 Dactílico

1.4.7 Dactílico

1.4.7 Dactílico

2.5.7 Heroico mixto

5. Sustituciones de esticomitias sobre patrones semánticos (A, B, C, D, E) y prosódicos (A, D, E) o sin ellos (B, C):

pero aunque el Zid yva solo A y pues solo quiere yr B
1.4.7 Dactílico

3.5.7 Melódico semipleno

45 Sigo la terminología de Elena Varela Merino, Pablo Moíno Sánchez y Pablo Jauralde Pou, Manual de métrica española, Castalia, Madrid, 2005 , p. 151. 
y aunque se pasea solo, $\mathrm{C}$ mas aunque solo salía D mas aunque solo salía $\mathrm{E}$
1.5.7 Enfático corto

1.4.7 Dactílico

1.4.7 Dactílico

6. Sustituciones de ideas completas sobre patrones silábicos en versos con rima o sin rima:

a solas yva pensando A, B, C, D

grandes cosas va pensando $\mathrm{E}$

Yendo pensando en aqueso A

y así, triste y pensativo $\mathrm{B}$

Y con estos pensamientos $\mathrm{C}$

Desta suerte, pensatiuo D

Desta suerte, pensatiuo E
2.4.7 Heroico puro

1.3.5.7 Melódico pleno

1.4.7 Dactílico

3.7 Melódico puro

3.7 Melódico puro

1.3.7 Melódico corto

1.3.7 Melódico corto

7. Amplificaciones con añadido de versos (la amplificación, por lo general, se construye con redundancias sobre los contenidos originales o complementos que estaban implícitos en la idea primaria) ${ }^{46}$.

El Ciid rebuelbe sobre ellos A

estas palabras hablando:

el cid rebuelue sobre ellos $\mathrm{B}$

desta manera hablando

El Çid rebuelue sobrellos D

desta manera á hablado:

El buen Cid que los á oýdo, C

reboluiendo su cauallo

las palabras que les dize

desta manera avía hablado:

Lo que puede deducirse de todas estas variantes es que los responsables de los cambios realizan operaciones estéticas cu-

${ }^{46}$ La comparación entre el testimonio A y C permite identificar las técnicas amplificatorias básicas, en las que parece dominar la unidad gramatical con acomodo libre dentro de la frase para matizar la acción: inclusión de adjetivos, inclusión de oraciones subordinadas, sintagmas nominales con función de complementos directos, circunstanciales, etc.

A

El Cid

rebuelbe sobre ellos

estas palabras

hablando
C

El [buen] Cid [que los á oýdo,]

reboluiendo [su cauallo] las palabras [que les dize] [desta manera] avía hablado: 
yos límites de afectación son estrictos: del lexema al verso, sin tocar de lleno la estructura narrativa. El compilador no enmienda de acuerdo con un esquema invasivo de mejoramiento, sino con uno tímido que considera que la estructura narrativa es intocable, mientras que las mejoras son necesarias en el plano de la expresión en unidades concretas (de la palabra al verso).

La transmisión impresa no podía permanecer ajena, por supuesto, a estos patrones de variación que se repiten durante la intensa vida de muchos romances exitosos. Aunque pesa el prejucio de una mayor estabilidad en los impresos, análisis más detenidos como el que realiza Giuseppe Di Stefano sobre los testimonios del Romance del Conde Alarcos ${ }^{47}$ permiten sorprender aquí y allá en los múltiples retoques al paso del proceso editorial un conjunto de cambios que van desde la regularización métrica, la modernización del léxico y otras sustituciones apresuradas, hasta cambios completos de versos (con los que se mejora la narrativa), omisiones significativas (como la censura sobre los versos en los que se describe cuando el conde desnuda a la condesa), revisión sistemática de la estereotipia propia del género para evitar la monotonía, etc. Lo que ha señalado Di Stefano respecto al recorte de versos, puede hacerse extensivo a las otras enmiendas vistas como

situaciones textuales en las cuales se advierte claramente una cuidadosa labor, típica de mesa de trabajo y de pluma; si atañen a testimonios colocados en las ramas altas del árbol genealógico, llevarían fácilmente a pensar en lo que la crítica de los textos cultos llama 'variantes de autor', categoría que en el Romancero no existe, ya que no se opone a otras categorías de variantes, siendo en principio todas "de autor" (ibid., p. 114).

Si revisamos las variantes consignadas por Di Stefano en su edición crítica sinóptica del Romance de don Tristán ${ }^{48}$, podemos advertir de nuevo una batería de cambios que coinci-

47 Giuseppe Di Stefano, "El Romance del conde Alarcos en sus ediciones del siglo xvi", pp. 111-129. El trabajo al que refiero se completa, por supuesto, con la edición crítica del romance por el mismo Di Stefano: "Il Romance del conde Alarcos. Edizione 'critica'”, en Symbolae pisanae, Studi in onore di Guido Mancini, a cura di B. Periñán e F. Guazzelli, Giardini, Pisa, 1989, t. 1, pp. 179-197.

48 G. Di Stefano, "El Romance de don Tristán. Edición 'crítica' y comentarios", en Studia in honorem prof. M. de Riquer, Quaderns Crema, Barcelona, 1988, t. 3, pp. 271-303. 
den con los de la transmisión manuscrita en el respeto a los límites léxicos, sintagmáticos y esticomíticos:

1. Adición u omisión de conjunciones expletivas:

y que no se halle hombre $L^{I}, 15$ ] Que no hallase maestro $\varepsilon, 17$

2. Sustituciones léxicas que respetan el patrón prosódico o silábico:

Váselo a ver doña Iseo $L^{I}, 9 \varepsilon, 11$ ] Valo a ver la reina Iseo $C R[47], 7$

3. Sustituciones sobre patrones semánticos, morfológicos y prosódicos:

Tanto están boca con boca $L^{I}, 17 \varepsilon, 19$ ] Júntanse boca con boca CR[47], 9

4. Sustituciones sobre patrones semánticos y prosódicos, pero con cambios morfológicos:

como una missa rezada $L^{I}, 18 \varepsilon, 20$ ] cuanto una missa rezada CR[47], 10

5. Sustituciones de esticomitias sobre patrones semánticos y prosódicos o sin ellos:

con una lança hervolada $L^{I}, 4$ ] con una lança enervolada $\varepsilon, 4$ ] por çelos que d'él catava CR[47], 4

la cama toda se vaña $L^{I}, 20$ ] toda la cama se baña $\varepsilon, 22$ ] la cama bañan en agua $C R[47], 12$ )

6. Sustituciones de ideas completas en versos con rima o sin rima: la su linda enamorada $L^{I}, 10 \varepsilon, 12$ ] por la su desdicha mala $C R[47], 8$ una zucena se regava $L^{I}, 22 \varepsilon, 24$ ] que açuçena se llamava $C R[47], 14$

7. Más amplificaciones construidas con redundancias o, si fuese en el sentido contrario, con la eliminación de las mismas redundancias:

Ferido está don Tristán de una mala lançada: diérasela el rey su tío
Ferido está don Tristán de una mala lançada: diérasela el rey su tío 
con una lança enervolada; por çelos que d'él catava

diósela desde una torre

e de cerca no osava,

qu'el hierro tiene en el cuerpo, el fierro tiene en el cuerpo

de fuera le tembla el asta $\varepsilon$

de fuera le tembla el asta $C R[47]$

Si la variación entre los impresos más modestos, los pliegos sueltos, era rica, habría de ser más conservadora en los libros, condicionada por su costo en dinero y tiempo (a mayor número de correcciones, mayor cargo en el conteo y composición de la forma y en el tiempo que aquello tomaría). En el caso de la Primera parte de la Silva de varios Romances impresa en Zaragoza en 1550 , por Esteban de Nájera ${ }^{49}$, copiada (o plagiada) sobre el modelo del Cancionero de romances, las variantes no son abundantes, pero cuando aparecen, caen en la misma tipología léxica, sintagmática y esticomítica que hemos advertido antes:

y yo no se le quise dare $1547-1548,170 \mathrm{v}]$ yo no se le quise dare 1550 , XCIIII v

una merced os pido señores / no me la queráis negare 1547-1548, 171r ] una merced os demando / queradesme la otorgare 1550, $\mathrm{XCV} r$

por mis hijos queráis mirare $1547-1548,171 v$ ] por ellos queráis mirare 1550 , XCVI V

para habella de degollare $1547-1548,172$ r ] para allí la degollare 1550 , XCVI v

alla le van a presentar 1547-1548, 174v ] llévanle a presentar 1550, XCVII V

señor pido vos por merced $1547-1548,137 \mathrm{r}$ ] Señor pido os por merced 1550, LVII r

49 Primera parte dela Silua de varios Romances. En que estan recopilados la mayor parte delos romances Castellanos que hasta agora se han compuesto II hay al fin algunas canciones: $\tau$ coplas graciosas y sentidas, Impresa en Çaragoça por Steuan S. de Ragera, 1550. Ejemplar de la Bayerische Staatsbibliothek, München, P. o. hisp. 179 1/2. (En línea, Googlebooks, http://books.google.com.mx/, fecha de consulta, 5 de enero de 2013, y en la página de la misma Bayerische Staatsbibliothek, http:/ /www.bsb-muenchen.de/index.php, fecha de consulta, 5 de enero de 2013). 
Las variantes léxicas, sintagmáticas y esticomíticas, en apariencia caprichosas, persiguen un fin común: corregir los versos hipermétricos en el modelo. El plano acústico de esta versión del Romancero llama suficientemente la atención como para corregir, en algún caso, una asonancia en á-e que se encuentra entre los asonantes del romance para no caer en la estereotipia:

hoy os quedaréis sin madre

caballeros de alta sangre

por mis hijos queráis mirare 1547-1548, 171v

hoy os quedaréis sin madre

caballeros de alta guisa

por ellos queráis mirare 1550, XCVI v

Lo más llamativo de los procesos de variación advertidos en el Romancero es que no se distinguen mucho de los que podemos encontrar en la poesía culta. La causa más probable quizá pueda atribuirse al halo de influencia de la imprenta, instrumento modélico para una época que condicionaría sin duda las modas de corrección y reescritura. Las pautas de variación vistas para el Romancero manuscrito e impreso se repiten, por ejemplo, en autores como fray Luis de León (sigo la tipología de variantes propuesta para el Romancero):

1. Adición u omisión de conjunciones expletivas:

1.1. aunque engañes los ojos $y$ aunque

1.2. deseo alto, honesto alto $y$ honesto

1.3. de Marte de furor y ardor ceñido de Marte $y$ de furor

1.4. olvidado, perdido olvidado y perdido
Ed. cit., núm. 16, v. 9 P M1 M4 M5 M6 M7 M8 M9

Ed. cit., núm. 4, v. 48 P3

Ed. cit., núm. 7, v. 10

Q2

Ed. cit., núm. 8, v. 19

P5 P7

2. Sustituciones léxicas sobre patrones prosódicos o silábicos (con variación en el ritmo del verso endecasílabo):

2.1. el río sacó fuera el pecho y le habló desta manera
Ed. cit., núm. 7, vv. 4-5

2.6.10 Heroico puro 
el pecho sacó fuera

el rio, y le habló desta manera

el río sacó fuera

la cabeza y habló desta manera
J J1 J2 J3 J4 J5 J6 J7 J8 J9 J12 J16

2.6.10 Heroico puro

J11 J13 J14 J15

3.6.10 Melódico puro

2.2. que del oro y del cetro pone olvido que del mundo y del sceptro pone olvido que del cetro y del mando pone olvido Ed. cit., núm. 1, v. 60 que del sceptro y del oro pone olvido y de la plata y oro pone olvido

2.3. guerra te cantaremos

Ed. cit., núm. 9, v. 58 te contaremos Q10 J1 J4J5 J6J8 R

2.4. con la aplicada cera suavemente sabiamente

Ed. cit., núm. 9, v. 65 J1 J4 J5 J6 J7 J8 R

3. Sustituciones sobre patrones semánticos, morfológicos y prosódicos:

3.1. ¡O monte, o fuente, o río! Ed. cit., núm. 1, v. 21

¡O campo, o monte, o río! ¡O monte, o campo, o río! B B1 B2 B3 C D1 D2 D3 D6 O S ¡O campo, o fuente, o río! $\mathrm{R}$ B4 D5 E

3.2. los que de un falso leño se confían Ed. cit., núm. 1, v. 62 los que de un flaco leño se confían J4 J5 J6 B C C1 C2 C3 C4 D D1 D2 D3 E O S R

los que de un frágil leño se confían B3 los que de un vano leño se confían C5 C7 D6

4. Sustituciones sobre patrones semánticos y prosódicos, pero con cambios morfológicos:

un día puro, alegre, libre quiero un día libre puro, alegre quiero Ed. cit., núm. 1, v. 27 un día alegre, bueno, vivir quiero $\mathrm{P}$ unos días alegres vivir quiero $\mathrm{B} 1$ un día puro, libre, alegre quiero D3 un día libre, claro, alegre quiero

5. Sustituciones de esticomitias sobre patrones semánticos y prosódicos o sin ellos:

de a quien la sangre ensalça, o el dinero Ed. cit., núm. 1, v. 30 de quien la sangre ensalza o el dinero del que sube la sangre o el dinero 
del que la sangre sube o el dinero

del que la sangre sube por dinero del que en sangre sube o en dinero del que la sangre os bebe por dinero
J B3 C2 C3 C4 C5 D2 D3

D4 D6 O

C8

D1

E

La presencia de sustituciones semejantes en ambos terrenos debe prevenirnos de ver en las variantes del Romancero una variante tradicional producto de la oralidad, pues las pautas de variación están en función de aquellos personajes capaces de poner por escrito igual un romance que unas liras de fray Luis, sea en el manuscrito, sea en un impreso, al margen de la tradición oral. Las variantes tienen otra lógica más compleja, con patrones de cambio comunes al autor genial y al humilde impresor. En el análisis de José Cebrián de los dos manuscritos autógrafos de Juan de la Cueva, uno de ellos con cuidadosas correcciones también autógrafas realizadas mediante tiras de papel encoladas sobrepuestas, se muestra una minuciosa corrección concentrada en las erratas de escaso interés ("i el cruel" por "i cruel"; "los dos perros" por "los perros", etc., art. cit., pp. 60-66), a no ser por sus consecuencias métricas. La comparación que hace Antonio Rey Hazas entre la versión manuscrita de los romances ariostescos de Pedro de Padilla (ms. 1579 de la Biblioteca Real de Madrid) con la versión impresa (1583), en la reciente edición de Labrador Herraiz y DiFranco, permite ver el taller del escritor, más allá de las versiones tradicionales que suponemos están detrás, como si los compiladores no fueran ellos mismos escritores ${ }^{50}$. En el caso de los romances de tema ariostesco, Rey Hazas ha hecho notar que nueve de los romances proceden del manuscrito,

aunque todos están revisados y, en algunos casos, muy bien enmendados, lo que demuestra que Padilla volvía sobre sus textos para rescribirlos y mejorarlos, consciente de su condición de escritor y del imprescindible rigor poético que debía presidir su obra impresa, muy lejos del mero improvisador de verso fácil que a veces se nos ha transmitido (ibid., p. 70).

El aspecto espontáneo de la transcripción y sus numerosas enmiendas han hecho pensar a sus editores, Labrador Herraiz y DiFranco, que se trata de

50 Antonio Rey Hazas, "Introducción al Romancero de Padilla”, en Pedro de Padilla, Romancero, p. 70. 
un cancionero todavía en borrador, con un mínimo orden, con poemas iniciados unos y terminados los más. Pero casi nunca en la forma definitiva, es decir, en la versión impresa... Al vuelo de la pluma los fue haciendo sobre los folios del cartapacio. Aunque no los componía en ese momento, porque algunos de ellos, los menos, han quedado tan limpios que sólo el tenerlos previamente escritos explicaría la ausencia de enmiendas y tachaduras ${ }^{51}$.

Si atendemos al único romance no ariostesco conservado en ambas fuentes, el sentencioso y moral "Galanes y caballeros / que de amor seguís el bando...", las variantes no difieren mucho de las variantes de compilador o transmisor vistas hasta aquí:

Ms. autógrafo

pues no ay cosa más discreta v. 7 traiga algo resfriado v. 22 estoy muy certificado v. 56 mas mi dolorá de ser v. 57 por descanso regalado v. 66
Impreso de 1583

pues no ay cosa más gallarda v. 7

le traen algo resfriado v. 22

estoy muy desengañado v. 46

Mas este mal no ha de ser v. 47

por contento regalado v. 56

Incluso en los momentos en los que las correcciones son abundantes y transforman el sentido original del romance, se trata de operaciones cosméticas localizadas, semejantes a las mejoras de impresores y compiladores:

Ms. autógrafo

Podrán estar enbidiosos los muy libres de mi estado, que si io tengo mi pena por descanso regalado, ¿para qué quiero más gloria que la que da mi cuidado? Juzgan los que no lo entienden que biuo desesperado, y es esto tan al revés en mí, que será escusado biuir de otra suerte vn ora si me viese libertado, porque tengo en mi tormento el gusto depossitado, y el descanso de mi vida en sólo biuir penado (ed. cit., núm. 166, vv. 63-78).
Impreso de 1583

Podrán estar embidiosos los más libres de mi estado, porque si tengo mi pena por contento regalado ¿para qué quiero más gloria que la que da mi cuydado? Juzgan los que no lo entienden que viuo desesperado, y es esto tan al rebés en mí, que será escusado viuir de otra suerte vn ora si me viesse libertado porque tengo en mi pasión el gusto depositado, y el regalo de mi vida en solo viuir penado (núm. 50, vv. 53-68).

51 "Estudio preliminar", en Cancionero autógrafo de Pedro de Padilla, ms. 1579 de la Biblioteca Real de Madrid, ed. de J.J. Labrador Herraiz y R.A. DiFranco, Moalde, PO, Guadalajara (España), 2007, p. 25. 
Las sustituciones son pocas y concisas. Pedro de Padilla pasa la versión manuscrita por la lima y sólo atina a un puñado de cambios que, al igual que haría un compilador o un impresor, respetan contenido y res metrica (en todos los casos, se conserva la densidad silábica, el perfil tónico y la carga semántica) y se ciñen a los límites estrictos y prácticos del lexema, del sintagma y del verso. En los vv. 66 (56 del impreso) y 77 (67 del impreso), Padilla advierte la repetición de "descanso" en la versión manuscrita y decide en ambos casos sustituir por la lectio difficilior, "regalo" y "pasión", respectivamente, en el impreso. Parecería que, ante la costumbre de leer con frecuencia las obras en cancioneros manuscritos, su puesta por escrito en uno de ellos le confiriera al texto cierta naturaleza inamovible. El paso a la imprenta implicaría nada más la posibilidad de enmendar errores, como la repetición de "descanso", pero sin llegar en verdad a la reconstrucción estética de más altos vuelos que podríamos esperar de la participación directa del autor.

En el fondo, las tímidas correcciones de Pedro de Padilla no se apartan de las correcciones del impresor o del compilador (se les puede aplicar la misma tipología ensayada antes) del siglo Xvi; cuando la obra se pone por escrito en un cancionero manuscrito, parecería que merece este lugar por haber alcanzado cierto estado de madurez. Mientras para el lector actual el manuscrito presenta una naturaleza provisional y caduca, para el autor del siglo Xvi parece investido por una estabilidad prestigiosa similar a la de cualquier impreso. El que el autor siga las modas de corrección que vemos en la variante editorial no debe sorprender, pues todo formaba parte de un mundillo literario común, donde el mismo autor fungía como lector de cancioneros manuscritos, romanceros impresos y pliegos sueltos, al tiempo que era compilador y aportaba sus correcciones al fluido cauce de la tradición, tanto al tratarse de obras propias como al compilar ajenas.

\section{CODA}

Resulta aleccionador advertir cómo en el cauce de la transmisión impresa y manuscrita se crean patrones de conducta seguidos por igual por autores literarios e impresores. Las posibilidades de corrección tampoco son enormes y hay que considerar que en muchos casos el autor estaría conforme con su 
obra; lo suficiente al menos como para volver a ella y sólo corregir lo más urgente. Si revisamos los borradores de "Scherzo para un elfo", de Luis Cernuda, con cierta licencia temporal, puede advertirse que la primera estrofa apenas está intervenida y que las sustituciones vuelven a ser estrictas en sus límites de afectación y en su respeto a los ejes léxicos, sintagmáticos y esticomíticos, sin descuidar la prosodia, tal como sucedía en el siglo xvı:

$\begin{array}{ll} & \text { A un fauno elfo } \\ & \text { Delicada criatura: } \\ & \text { No deseo a mi voz } \\ & \text { que turbe el embeleso } \\ \text { Tanarillo } & \text { Tágieo del bosque, } \\ & \text { Tu elemento nativo, } \\ & \text { por tas verdes* columnas *vívidas } \\ & \text { Sustentado hasta el vuelo }{ }^{52} \text {. }\end{array}$

En el caso del título, desaparece el guiño a Mallarmé del "fauno" y se sustituye por un "elfo"; el embeleso "tan mágico" gana un poco de misterio al aplicar la paleta cromática y describirlo como "amarillo", pero la modificación recarga el colorido del poema al llegar a "las verdes columnas" (adjetivo, por otro lado, obvio para referirse a los árboles del paisaje), columnas que serán, en una nueva versión, "vívidas". En los tres cambios se reconocerá una voluntad de renovación y mantenimiento (muy obvia para fauno/ elfo o verdes/vívidas, menos obvia en amarillo/tan mágico). En otros casos, donde las enmiendas resultan mayores, Cernuda sustituye esticomitias completas, aunque sin perder de vista el sentido ni la prosodia del heptasílabo dominante:

Primera campaña:

Łigero como un sueño circulas en la niebla

Segunda campaña:

Con paso gris de sueño circulas en la niebla

${ }^{52}$ Luis Cernuda, Cinco elegías españolas, versiones autógrafas inéditas (1937), edición facsímil, Caballo Griego para la Poesía, Madrid, 2002, s/p. 
El mundo de la composición artística, moderno y antiguo, es una paleta compleja de operaciones diferentes que coinciden, me parece, en un punto: la voluntad de mejorar la obra, desde el autor hasta el impresor o el copista, mediante pequeñas intervenciones que no dañen la estructura interna, métrica y narrativa en estos casos. La autoridad que hoy tiene la enmienda de autor, sin embargo, parece un poco inusitada ante la evidencia antigua: en el caso del Romancero, al menos, resulta difícil distinguir entre los mecanismos de transformación de las obras literarias ejercidas por el autor del trabajo de sus casi pares, los compiladores (muchos de ellos también poetas y lectores activos) e impresores. A menudo, su intervención se mira con recelo, pero en un mundo donde la poesía era una técnica y los aficionados a ella eran tantos y muchos con tan buen tino, no estoy seguro de que podamos mantener en todos los casos la existencia de una idealizada lección primigenia de autor enfrentada a muchas otras lecciones que tampoco faltan a la razón, ni métrica ni narrativamente.

$\mathrm{Si}$, como ha demostrado el grupo de trabajo que publicó recientemente Del impreso al manuscrito en los cancioneros ${ }^{53}$, en la poesía de autor hay un canon de transmisión centrado en el prestigio del impreso (donde la letra de molde funciona como un textus receptus, por lo que el impreso puede funcionar como antígrafo de un manuscrito cuando ya no está disponible para su compra, el manuscrito ha perdido folios o, simplemente, como una autoridad para verificar la autenticidad de la lectura en el manuscrito, la autoría de la composición, etc.); en el caso del Romancero, ni el pliego suelto ni el cancionero alcanzan esta autoridad de forma fácil y muy pronto se convierten en otro canal más de transmisión, que se respeta por comodidad en los talleres editoriales (siempre resulta más sencillo formar un texto desde un impreso que desde un manuscrito), pero en el ámbito de su circulación ofrece un panorama muy rico y complejo, de ida y vuelta de los impresos o de una vida independiente, al margen de una imprenta comercial, pero impulsado al mismo tiempo por ella. Este panorama sugiere una forma diferente de entender y valorar el mundo del manuscrito y del impreso, con lecciones confiables que, cuan-

53 Josep Lluís Martos (coord. y ed.), Del impreso al manuscrito en los cancioneros, Centro de Estudios Cervantinos, Alcalá de Henares, 2011, pp. 207-211. 
do merecían un cambio, fuera en manos de su autor o de un compilador, se cumplía sin perder de vista su naturaleza perfectible, dentro de ciertos límites. En un mundo de colaboradores, de lectores participativos, de censores del impreso anónimo y de autor, de impresores metidos a poetas y de poetas metidos a imprimir sus obras, de autores que despreciaron publicar en vida, de autores que publicaron mucho sin dejar apenas constancia de sus nombres, los distingos entre variantes de autor, variantes de compilador y variantes editoriales resultan difíciles, pues todas parecen responder a una misma fuerza centrífuga que arrastra las cosas a su centro para: 1) mejorar las lecciones siempre que esto fuera posible y con una orientación de la mejora profundamente personal y 2) respetar la métrica del verso y no afectar de modo sustancial el desarrollo narrativo de la historia. Ambas, a menudo, sin importar si se trataba de un autor, de un compilador o de un impresor, figuras claras para nosotros hoy, pero con límites difusos para el lector del siglo XVI.

Alejandro Higashi Universidad Autónoma Metropolitana 